\title{
Spatial Distribution of Chlorophyll-a and Its Relationship with Dissolved Inorganic Phosphate Influenced by Rivers in the North Coast of Java
}

\author{
Lilik Maslukah ${ }^{1,2}$, Muhammad Zainuri' ${ }^{2}$, Anindya Wirasatriya ${ }^{2,3}$, Ummu Salma ${ }^{2,4}$ \\ 1 Doctoral Program of Marine Science, Faculty of Fisheries and Marine Science, Diponegoro University, \\ Indonesia \\ 2 Department of Oceanography, Faculty of Fisheries and Marine Science, Diponegoro University, Indonesia \\ ${ }^{3}$ Center for Coastal Rehabilitation and Mitigation Studies, Diponegoro University Indonesia \\ ${ }^{4}$ Undergraduate Program of Oceanography, Faculty of Fisheries and Marine Science, Diponegoro University, \\ Indonesia \\ *Corresponding author's e-mail: lilik_masluka@yahoo.com
}

\begin{abstract}
This research examines the eutrophication process mainly by considering the chlorophyll-a concentration. A simple linear model was used to determine the correlation between Chlorophyll-a and dissolved inorganic phosphate (DIP). The research was carried out on river mouths in the north coast of Central Java. The results of the linear model show that the relationship between chlorophyll-a and DIP follows the logarithmic model with the log [Chloa] $=1.52+1.60 \log [\mathrm{DIP}], \mathrm{R}^{2}=0.55$. The model suggests that the high concentration of chlorophyll-a is related to dissolved inorganic phosphate concentrations. On the basis of the sufficient of conclusive evidence for these variables, the study sites with high stresses from several anthropogenic sources had higher chlorophyll-a than the sites that are relatively far from river mouths and lands.
\end{abstract}

\section{INTRODUCTION}

Human activities have adversely affected the coastal water systems because of the increase of pollutants introduced to the estuarine through river flows (Cong et al., 2006; Li et al., 2010; Maslukah et al. 2019; Wang et al., 2015). One of these ecological impacts is the increase in water fertility (eutrophication) caused by an increase in $\mathrm{N}$ and $\mathrm{P}$ nutrients input into the waters (Maslukah et al., 2018 ). A study carried out by Maslukah et al. (2018 ) shows that $\mathrm{N}$ and $\mathrm{P}$ nutrients from the Serang and Wiso Rivers entering the waters of Jepara reached up to 19.66 tons/month and 2.15 tons/month, respectively, resulting in an increase of chlorophyll-a in the waters at $0.55-5.21 \mathrm{mg} / \mathrm{m}^{3}$ (mean value $1.29 \mathrm{mg} / \mathrm{m}^{3}$ ). Meanwhile, the research conducted by Subiyanto (2017) in the river of Banjir Kanal Barat (BKB) suggested that the concentration of chlorophyll-a is extremely high and the water conditions are considered at the eutrophic level. The chlorophyll-a concentration is often used to estimate the phytoplankton biomass and aquatic productivity that further can be used as consideration in the context of marine resource management and monitoring of water quality (Zhang and Han, 2015; Agirbas et al., 2017).

Phytoplankton is the primary producer of the aquatic environment, and accounts for up to $50 \%$ of the world's primary production (Poornima et al., 2014). The growth of phytoplankton in estuaries and coastal seas depends on several parameters, including the availability of nutrients, the penetration, and intensity of light and the mixing process. Nutrient availability is often considered a key factor regulating phytoplankton growth, biomass composition and species diversity (Roelke et al., 1999, Li et al., 2010). Moreover, nitrogen and phosphorus (Schindler, 1977) have been identified as the most common nutrients 
limiting the phytoplankton production in marine and freshwater ecosystems (Hecky and Kilham, 1988; Elser et al., 1990; Dodds et al., 2016).

Phosphorus (P) plays an essential role in the transformation of energy during the photosynthesis of phytoplankton. This element is necessary for the metabolic processes of algae, including the synthesis of nucleotides, phospholipids and sugar phosphates (Wetzel, 1983). Diatoms reached the limits of their growth with the available P (Trommer et al. 2013 and Poornima et al. 2014). Hydrological systems rich in $\mathrm{P}$ elements can use nitrogen $(\mathrm{N})$ and carbon $(\mathrm{C})$ from the atmosphere for algae production, leading to a significant increase in primary ecosystem production. Even though, the increase in phosphorus $(\mathrm{P})$ promotes the development of cyanobacteria, the increase in $\mathrm{C}$ or $\mathrm{N}$ without the P-enrichment effect is negligible (Schindler, 1974).

The waters in the north coast of Central Java collect a freshwater stream from large rivers such as Banjir Kanal Barat (BKB) and Banjir Kanal Timur (BKT) rivers in Semarang, Serang and Wiso rivers in Jepara, the Sragi river in Pekalongan and the Kendal river in Kendal. It is widely known that the existence of various upstream activities and conditions will influence the nutrient inputs to rivers and coastal waters proportionally. The study carried out by Maslukah et al. $\left(2018^{b}\right)$ in Jepara waters indicates that the nutrient concentrations and river flow affect the magnitude of the nutrient input. It was also explained that the conditions in different watersheds could affect the nutrient concentrations of N, P and, subsequently, the chlorophyll-a concentration. Chlorophyll-a is the most important component of phytoplankton that can be used as an indicator of eutrophication. Even though nutrients lead to plankton abundance followed by rising of fish production, the excessive richness of nutrients is responsible for the low oxygen content that can culminate in dead zones.

The role of nutrients $\mathrm{N}, \mathrm{P}$ and its ratio has been widely reported in lake waters (Elser et al. 1990; Elser et al. 2007; Bennet et al. 2017; Dodds et al. 2016); however, it remains limited mainly in the marine environment (Poormina et al., 2014). $\mathrm{P}$ is known to be the limiting factor in the freshwater environment, while $\mathrm{N}$ is regarded as a limiting factor in the estuary, sea, and waters between them (Hecky and Kilham, 1988). However, the discussion over the relative role of these two nutrients in control lake eutrophication is still on-going. Howarth and Paerl (2008), Lewis and Wurtsbaugh (2008), Paerl (2009) suggested that $\mathrm{N}$ plays an important role, while on the contrary, a considerable amount of works have argued that limiting the P input is sufficient to control eutrophication (Schindler and Hecky 2008, Schindler et al. 2008, Schindler 2012). A previous work conducted by Maslukah et al. (2018 $)$ in Jepara coastal waters, Indonesia, demonstrated that nutrient-rich nitrogen should also be balanced with both $\mathrm{P}$ element and $\mathrm{P}$ nutrients as a nutrient limiting factor, especially when chlorophyll-a is found to be high. In addition, it was explained that the distribution pattern of chlorophyll-a in Jepara waters follows the phosphate distribution pattern. On the basis of this information, the present study aims at examining the response of chlorophyll-a in river mouths in Central Java and their association with the dissolved phosphorus (P) concentration.

\section{MATERIALS AND METHODS}

The study site includes two river mouths located in the city of Semarang (Banjir Kanal Barat dan Banjir Kanal Timur), in the regency of Kendal (Kendal River), in the regency of Pekalongan (Sragi River estuary) and two river mouths in the regency of Jepara district (Serang and Wiso). The data of phosphate and chlorophyll-a in Jepara is based on the previous study carried out by Maslukah $\left(2018^{b}\right)$. This research was conducted in June and November 2017.

The water samples were collected at the surface using a water sampler $(0.2 \mathrm{D}, \mathrm{D}=$ water depth). The samples for the nutrient $\mathrm{P}$ (phosphate) and chlorophyll analyses were transferred to polyethylene sample vials. Prior to the water sampling, the bottles were washed with the same water sample. As for the laboratory analysis, $500 \mathrm{ml}$ of the sample was filtered with Millipore filter paper (pores size $0.45 \mu \mathrm{m}$ ). The samples were directly analyzed on the same day. Otherwise, the samples were frozen and analyzed the next day (Chale, 2004; Maslukah et al., 2018 ${ }^{\mathrm{b}}$ ).

The analysis of the dissolved nutrient $\mathrm{P}$ was done by using a technique called an ascorbic acid method, in which the orthophosphate concentration was determined (APHA, 1992) using the absorbance value calculated with UVVIS Shimadzu 3600 Spectrophotometer, with a cuvette width of $1 \mathrm{~cm}$. 


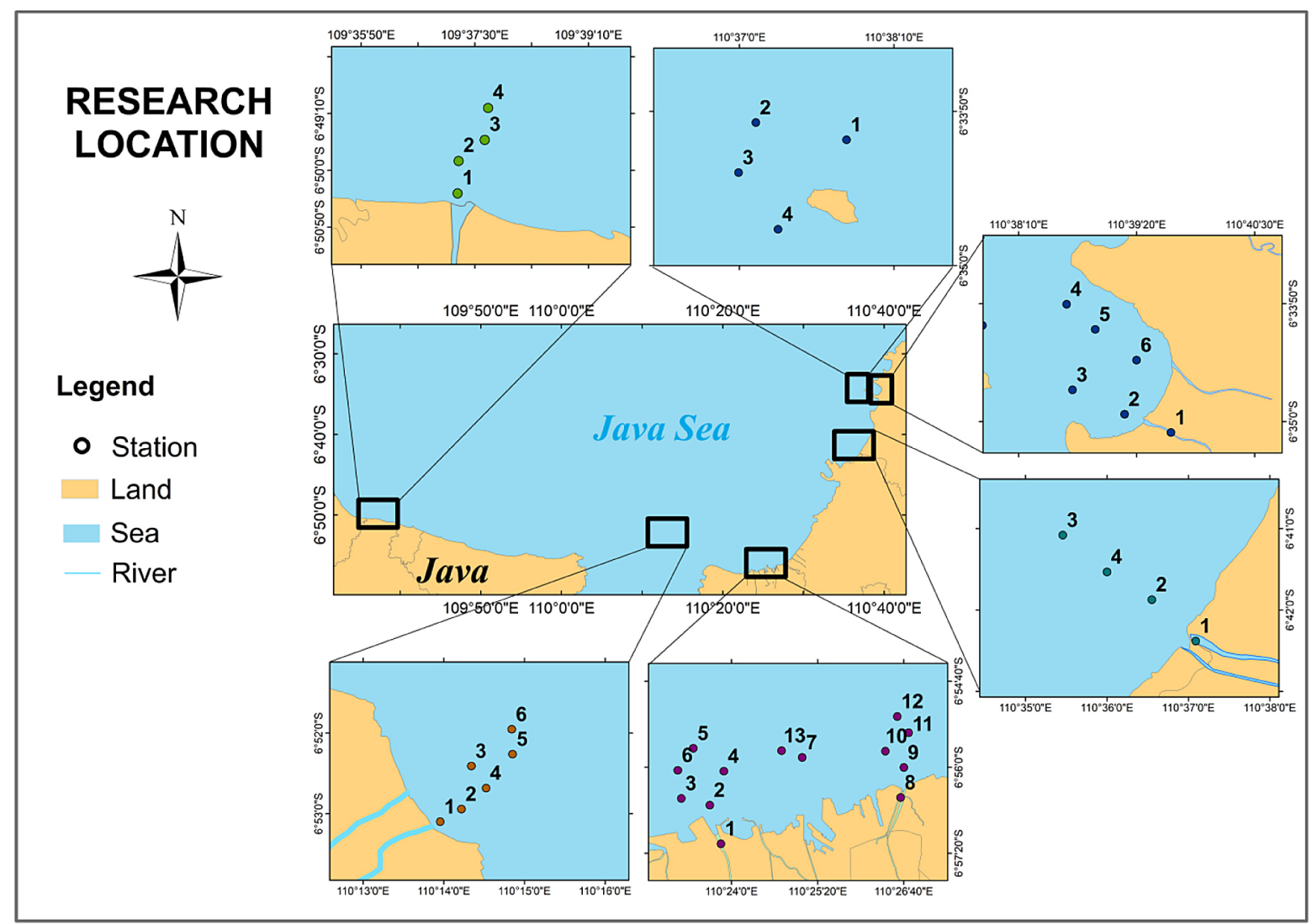

Fig. 1. The study site

Furthermore, as far as the determination of the chlorophyll-a concentration is concerned; 1 liter of seawater was filtered using Millipore filter paper $(0.45 \mu \mathrm{m}$ pore size $)$. The filtrate was extracted with $10 \mathrm{ml}$ of $90 \%$ acetone, and it was stored overnight in a fridge in darkness for 16 hours, then it was centrifuged at $4000 \mathrm{rpm}$ (Maslukah et al. 2018b). The supernatant absorbance then was observed at wavelengths 664,647 and 630, where the wavelength of 750 was used as a turbidity control. The chlorophyll-a concentration was calculated using the following formula:

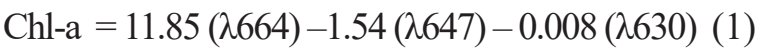

Concentration of Chl-a $\left(\mathrm{mg} \cdot \mathrm{m}^{-3}\right)=\mathrm{Ca} \times \frac{v}{V}$

where: $\lambda 664-$ value of absorbance at wavelength $664 \mathrm{~nm}$,

$\lambda 645$ - value of absorbance at wavelength $645 \mathrm{~nm}$,

$\lambda 630$ - value of absorbance at wavelength $630 \mathrm{~nm}$,

$V$ - volume of extract (liter),

$V$-volume of sample $\left(\mathrm{m}^{3}\right)$.

The analysis was peformed using the Kruskal Wallis test in order to determine the differences in average nutrient and chlorophyll concentrations at different locations. $\mathrm{P}<0.05$ were considered being significantly different. Then, the Bonferroni test was used to determine the differences between the locations. The relationship model of the DIP between nutrient and chlorophyll-a was achieved by using a simple linear regression model. The relationship between the dependent and the independent variable(s) in a regression model may be (a) simple, (b) multiple or (c) stepwise regression. Although the linear regression has been used extensively in phytoplanktonic and eutrophication studies, mainly to study the effects of nutrient on phytoplankton variables, it is still uncertain whether the researchers have always examined the very strict assumptions of the simple linear regression (Poole, 1974). The data were analyzed by means of statistical software SPSS v. 18 and Microsoft Office Excel 2007. The data were subjected to correlattion and Bivariate test to find a significant relationship between chlorophyll a and the phosphate concentration. 


\section{RESULTS AND DISCUSSION}

The results show that dissolved inorganic phosphate (DIP) concentrations in northern waters of Central Java ranged from 0.19 to $0.69 \mu \mathrm{mol} \mathrm{L}^{-1}$ (Table 1). The lowest DIP was found in Panjang island, Jepara and the highest concentration was found on the Banjir Kanal Barat in Semarang. The variations of the DIP are most likely related to human activities in the region. Unlike BKB, Panjang island is located far from land-based activities.

The presence of this dissolved nutrient phosphate will certainly affect the fertility of the water. The indicator used in this study is chlorophyll a. The measured values of chlorophyll-a in this study were between 0.97 and $21.09 \mu \mathrm{g} \mathrm{L}^{-1}$. The

Table 1. Soluble inorganic phosphate (DIP) and chlorophyll-a concentrations in several estuaries of the northern coast of Central Java

\begin{tabular}{|c|c|c|c|}
\hline Location & Station & DIP Concentration $(\mu \mathrm{M})$ & Chlorophyll-a $\left(\mathrm{mg} / \mathrm{m}^{3}\right)$ \\
\hline \multirow[t]{5}{*}{ River Mouth of Wiso } & 1 & 0.39 & 5.62 \\
\hline & 2 & 0.23 & 4.72 \\
\hline & 3 & 0.37 & 4.49 \\
\hline & 4 & 0.39 & 4.81 \\
\hline & 5 & 0.40 & 5.14 \\
\hline Average & & 0.36 & 4.95 \\
\hline Standard Deviation & & 0.07 & 0.44 \\
\hline \multirow[t]{5}{*}{ Panjang Island } & 1 & 0.31 & 2.23 \\
\hline & 2 & 0.19 & 1.08 \\
\hline & 3 & 0.22 & 0.97 \\
\hline & 4 & 0.23 & 1.36 \\
\hline & 5 & 0.22 & 1.43 \\
\hline Average & & 0.24 & 1.53 \\
\hline Standard Deviation & & 0.05 & 1.60 \\
\hline \multirow[t]{4}{*}{ River Mouth of Serang } & 1 & 0.66 & 6.48 \\
\hline & 2 & 0.25 & 7.01 \\
\hline & 3 & 0.30 & 5.45 \\
\hline & 4 & 0.25 & 5.73 \\
\hline Average & & 0.36 & 6.17 \\
\hline Standard Deviation & & 0.20 & 0.71 \\
\hline \multirow[t]{5}{*}{ BKT, Semarang } & 1 & 5.08 & 12.86 \\
\hline & 2 & 4.23 & 11.77 \\
\hline & 3 & 0.56 & 7.13 \\
\hline & 4 & 0.45 & 10.70 \\
\hline & 5 & 0.43 & 21.09 \\
\hline Average & & 0.51 & 12.67 \\
\hline Standard Deviation & & 0.08 & 5.95 \\
\hline \multirow[t]{5}{*}{ BKB, Semarang } & 1 & 0.69 & 20.40 \\
\hline & 2 & 0.52 & 17.37 \\
\hline & 3 & 0.43 & 12.97 \\
\hline & 4 & 0.49 & 9.09 \\
\hline & 5 & 0.51 & 16.56 \\
\hline Average & & 0.53 & 15.28 \\
\hline Standard Deviation & & 0.10 & 4.36 \\
\hline \multirow[t]{4}{*}{ Kendal River } & 1 & 0.74 & 7.97 \\
\hline & 2 & 0.75 & 8.17 \\
\hline & 3 & 0.62 & 7.34 \\
\hline & 4 & 0.49 & 3.94 \\
\hline Average & & 0.40 & 9.33 \\
\hline Standard Deviation & & 0.15 & 3.02 \\
\hline \multirow[t]{4}{*}{ Sragi River Pekalongan } & 1 & 0.48 & 5.53 \\
\hline & 2 & 0.40 & 5.11 \\
\hline & 3 & 0.38 & 3.64 \\
\hline & 4 & 0.33 & 3.78 \\
\hline Average & & 0.40 & 4.52 \\
\hline Standard Deviation & & 0.06 & 0.95 \\
\hline
\end{tabular}


lowest concentration was found at the Panjang island while the highest concentration was at Banjir Kanal Timur. It is almost certain that the anthropogenic process on the land has a very significant impact on water fertility. The study carried out by Maslukah et al. $\left(2018^{\mathrm{b}}\right)$ indicated that the chlorophyll-a concentration follows the phosphate distribution pattern. In addition, Shaari et al. (2013) and Cong et al. (2006) emphasized that the influence of land through river runoff results in significant nutrient inputs to the coastal waters. The high nutrient content leads to the increase of chlorophyll-a in the waters nearby the river mouths. Nuzapril et al. (2017) also reported that the waters nearby the land have higher chlorophyll-a due to higher nutrient inputs. The river flow is also one of the factors affecting phytoplankton in coastal waters, particularly in the estuaries (Wang et al., 2015). The presence of chlorophyll-a may be used as an indicator of phytoplankton biomass. Furthermore, the study conducted by Maslukah et al. $\left(2018^{b}\right)$ demonstrated that the rivers with large drainage basins and high flows contribute to the increase in chlorophyll-a. The laboratory simulations carried out by Poornima et al. (2017) on phosphorus enrichment at a concentration of 0.18 $\mu \mathrm{M}$ allowed the chlorophyll a concentration to reach $2.01 \mu \mathrm{g} \mathrm{L}^{-1}$.

The tabulation for each region that is shown in Fig. 2. indicates that there is a response to the increase and decrease in chlorophyll-a due to the changes in dissolved phosphate (DIP) concentration, although its correlation is visually nonlinear.

Figure 2 shows that the BKB site has the highest concentration of phosphate nutrients. This has also been shown to influence the increase in chlorophyll-a concentration. The high concentration of nutrients and chlorophyll-a in the Semarang region (BKT and $\mathrm{BKB}$ ) is most likely due to very strong anthropogenic activity on land. Semarang is a capital city of Central Java with the largest population compared with other study sites. In addition, this region is well-known as the center of industrial development in Central Java. The results of the previous studies conducted by Subiyanto (2017) also correlated with this finding, where BKB was categorized as a eutrophic zone. The distribution model on the north coast of Java is presented in Figure 3.

Chlorophyll-a may be used as a biomarker in aquatic ecosystems (Picado et al., 2014). In addition, Wu et al. (2009) suggested that chlorophyll could be used as a guide for environmental protection and the mechanism of a fishing area. The abundance of chlorophyll-a indicates the process of eutrophication that affects the dynamics of the marine biogeochemical ecosystem and could lead to many future events following the reactions to the increasing influence of human activity on the marine environment (Wang et al, 2015). Li et al (2010) reported that the increase in water containing the $\mathrm{N}$ and $\mathrm{P}$ nutrients resulted mainly due to human activities.

On the basis of the statistical tests using the Kruskal Wallis test, there were differences in dissolved phosphate and chlorophyll-a concentrations in some study sites at a significance level $<0.05$ (Table 2). In order to recognize the differences between each location, the multiple comparisons were employed (Table 3 ), It can be seen in Table 3 that the difference in DIP is found

Table 2. Statistics test using Kruskal Wallis test

\begin{tabular}{|c|c|c|}
\hline & DIP & Chlo-a \\
\hline Chi-Square & 16.204 & 24.965 \\
\hline $\mathrm{df}$ & 6 & 6 \\
\hline Asymp. Sig. & 0.013 & 0.000 \\
\hline
\end{tabular}

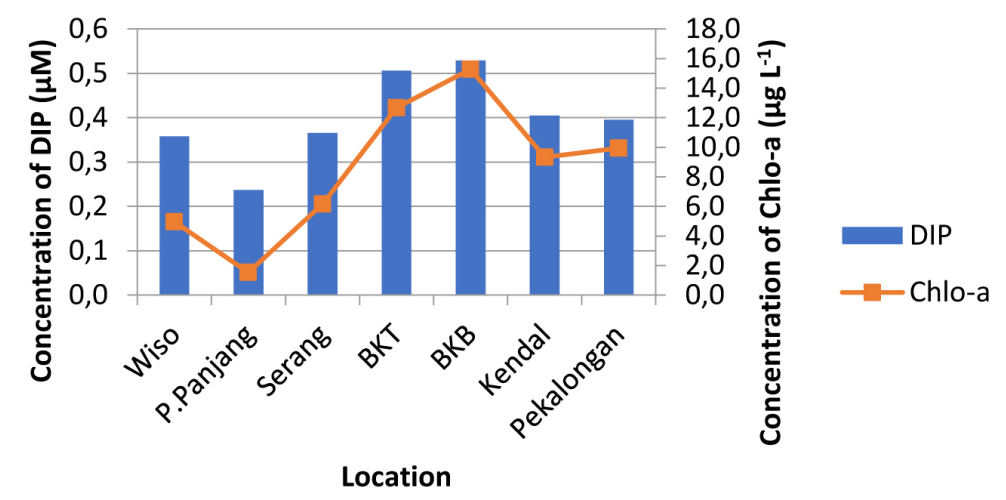

Fig. 2. Concentrations of dissolved organic phosphate (DIP) and chlorophyll on each study site 
Table 3. Multiple comparisons DIP and chlorophyll on each study site (Bonferroni test)

\begin{tabular}{|c|c|c|c|c|c|c|c|}
\hline \multirow{2}{*}{$\begin{array}{l}\text { Dependent } \\
\text { Variable }\end{array}$} & \multirow{2}{*}{ (I) location } & \multirow{2}{*}{ (J) location } & \multirow{2}{*}{$\begin{array}{c}\text { Mean } \\
\text { Difference } \\
(\mathrm{I}-\mathrm{J})\end{array}$} & \multirow{2}{*}{ Std. Error } & \multirow{2}{*}{ Sig. } & \multicolumn{2}{|c|}{ 95\% Confidence Interval } \\
\hline & & & & & & Lower Bound & Upper Bound \\
\hline \multirow{6}{*}{ DIP } & \multirow{6}{*}{ Panjang } & Wiso & -.12068 & .07394 & 1.000 & -.3731 & .1317 \\
\hline & & Serang & -.12834 & .07794 & 1.000 & -.3944 & .1377 \\
\hline & & BKT & $-.26881^{*}$ & .07794 & .046 & -.5348 & -.0028 \\
\hline & & BKB & $-.29173^{*}$ & .07394 & .014 & -.5441 & -.0394 \\
\hline & & Kendal & -.16792 & .07794 & .880 & -.4339 & .0981 \\
\hline & & Sragi & -.15871 & .07794 & 1.000 & -.4247 & .1073 \\
\hline \multirow{6}{*}{ Chlo-a } & \multirow{6}{*}{ Panjang } & Wiso & -3.43100 & 2.05223 & 1.000 & -10.4357 & 3.5737 \\
\hline & & Serang & -4.64250 & 2.16324 & .896 & -12.0261 & 2.7411 \\
\hline & & BKT & $-11.14750^{*}$ & 2.16324 & .001 & -18.5311 & -3.7639 \\
\hline & & BKB & $-13.75300^{*}$ & 2.05223 & .000 & -20.7577 & -6.7483 \\
\hline & & Kendal & $-7.80250^{*}$ & 2.16324 & .031 & -15.1861 & -.4189 \\
\hline & & Sragi & $-8.41000^{*}$ & 2.16324 & .016 & -15.7936 & -1.0264 \\
\hline
\end{tabular}

between Panjang island with the estuary of BKB and BKT $(\mathrm{p}<0.05)$. In addition, the location of the chlorophyll-a concentration in Panjang island is identical with the adjacent region, located in Jepara waters (Wiso and Serang), but these three locations greatly differ from the location of the western region (Semarang, Kendal, and Pekalongan).

In comparison with the study reported by Agirbas et al. (2017) the chlorophyll-a concentration in the southeast of the Black Sea reached up to $0.34 \mathrm{mg} \mathrm{L}^{-1}$ to $2.71 \mathrm{mg} \mathrm{L}^{-1}\left(\sim 340-2,710 \mu \mathrm{g} \mathrm{L}^{-1}\right)$.

The relationship model between the DIP and chlorophyll-a concentration can be described on a logarithmic model with the formula $\log [$ Chlo-a $]=1.52+1.60 \log [\mathrm{P}]$, with a correlation coefficient (r) of 0.74 , the coefficient of determination $\left(\mathrm{R}^{2}\right)=0.55, \mathrm{p}<0.05$ and $\mathrm{n}=29$. These determination values demonstrate that the presence of a chlorophyll-a is not determined solely by the presence of dissolved inorganic phosphate (DIP). However, the contribution of this DIP plays a significant role in determining the chlorophyll-a concentration. The previous studies conducted by Dillon and Rigler (1974) in lake waters showed that the correlation of $\mathrm{P}$ with chlorophylla might reach 0.90 with the $\log$ model formula $[\mathrm{Chl}$ a] $=1,449 \log$ [PI-1 136. In turn, the study carried out by Bbalali et al. (2013) reported that there was no relationship between chlorophyll-a and phosphate which was described by the following model of $\log \mathrm{Chl} \mathrm{a}=0.017 \mathrm{PO} 4+1.519$ with $\mathrm{R} 2=0.000, \mathrm{r}=0.005$.

\section{CONCLUSION}

Anthropogenic processes highly influence the distribution of chlorophyll-a in the north coast of Central Java. The eastern region (Jepara: Wiso, Serang and P. Panjang) has a lower concentration compared with the western region (Semarang). Pulau Panjang, located furthest from the Java Island, has the lowest water fertility. The existence of dissolved inorganic phosphates greatly affects the water fertility. The results of a simple linear model analysis between phosphate and chlorophyll-a relationship follow the $\log$ model $[$ Chlo-a] $=1.52+1.60 \log [\mathrm{P}]$, with a correlation coefficient (r) of 0.74 , the determination coefficient $\left(\mathrm{R}^{2}\right)=0.55$. This model shows the chlorophyll-a is mainly driven by the presence of phosphate that contributed to up to $55 \%$, while the other factors account for $45 \%$.

\section{Acknowledgments}

This research was funded with biaya selain APBN DPA SUKPA Faculty of Fisheries and Marine Science, Diponegoro University, budgeting year of 2019.

\section{REFERENCES}

1. Agirbas, E., L. Koca, U. Aytan . 2017. Spatio-temporal pattern of phytoplankton and pigment composition in surface waters of south-eastern Black Sea. Oceanologia, 59, 283-299. 
2. APHA. 1992. Standart Method for the Examination of Water and Wastewater. 18th edition. Washington, p. 252.

3. Bennett, M. G., Schofield K. A., Lee S. S. \& Norton, S. B. 2017. Response of chlorophyll a to total nitrogen and total phosphorus concentrations in lotic ecosystems: a systematic review protocol. Environmental Evidence, 6(18), 1-13.

4. Chale, F.M.M. 2004. Inorganic nutrient concentrations and chlorophyll in the euphotic zone of Lake Tanganyika.Hydrobiologia. 523, 189-197.

5. Dillon, P.J and F. H. Rigler. 1974. The phosphoruschlorophyll relationship in lakes. Limnology and Oceanography, 19 (5), 767-773.

6. Dodds, W. K. \& Smith, V. H. 2016. Nitrogen, phosphorus, and eutrophication in streams. Inland Waters (2016) 6, 155-164.

7. Elser JJ, Marzolf ER, Goldman CR. 1990. Phosphorus and nitrogen limitation of phytoplankton growth in the freshwaters of North America: a review and critique of experimental enrichments. Can J Fish Aquat Sci. 47, 1468-1477.

8. Elser JJ, Bracken ME, Cleland EE, Gruner DS, Harpole WS, Hillebrand H, Ngai JT, Seabloom EW, Shurin JB, Smith JE. 2007. Global analysis of nitrogen and phosphorus limitation of primary producers in freshwater, marine and terrestrial ecosystems. Ecol Lett. 10, 1135-1142.

9. Hecky RE, Kilham P. 1988. Nutrient limitation of phytoplankton in freshwater and marine environments: a review of recent evidence on the effects of enrichment. Limnol Oceanogr. 33, 796-822.

10. Howarth R, Paerl HW. 2008. Coastal marine eutrophication: control of both nitrogen and phosphorus is necessary. P Natl Acad Sci USA. 105, E103.

11. Lewis WM Jr, Wurtsbaugh WA. 2008. Control of lacustrine phytoplankton by nutrients: erosion of the phosphorus paradigm. Int Rev Hydrobiol. 93, 446-465.

12. Li, W. K. W., M. R. Lewis, \& W. G. Harrison. 2010. Multiscalarity of the Nutrient-Chlorophyll Relationship in Coastal Phytoplankton. Estuaries and Coasts, 33, 440-447.

13. Maslukah, L., S. Y. Wulandari \& I. B. Prasetyawan. 2018a. The Estuaries Contribution for Supplying Nutrients ( $\mathrm{N}$ and $\mathrm{P}$ ) in Jepara Using Numerical Modelling Approach. IOP Conf. Series: Earth and Environmental Science. (116), 1-10.

14. Maslukah, L., S. Y. Wulandari \& I. B. Prasetyawan. 2018b. The Distributions of N, P Nutrients And Its Relations with Chlorophyll-A: Case Study In Serang And Wiso Estuary, Jepara, Indonesia. Asian Jr. of Microbiol. Biotech. Env. Sc. 20 (3), 821-827.

15. Maslukah, L, S. Y. Wulandari, I. B. Prasetyawan, M. Zainuri. 2019. Distributions and Fluxes of Ni- trogen and Phosphorus Nutrients in Porewater Sediments in the Estuary of Jepara Indonesia. Journal of Ecological Engineering. 20 (2), 58-64.

16. Nuzapril, M, S. B. Susilo, J. P. Panjaitan. 2017. Relationship Between Chlorophyll-A Concentration With Primary Productivity Rate Using Landsat 8 Imagery. Jurnal Teknologi Perikanan dan Kelau$\tan .8$ (1), 105-114.

17. Paerl HW. 2009. Controlling eutrophication along the freshwater-marine continuum: dual nutrient $(\mathrm{N}$ and $\mathrm{P}$ ) reductions are essential. Estuar Coast. 32, 593-601.

18. Paerl HW, Hall NS, Peierls BL, Rossignol KL. 2014. Evolving paradigms and challenges in estuarine and coastal eutrophication dynamics in a culturally and climatically stressed world. Estuar Coast. 37, 243-258.

19. Picado, A.; Alvarez, I.; Vaz, N.; Varela, R.; GomezGesteira, M.; Dias, J.M. Assessment of chlorophyll variability along the Northwestern Coast of Iberian Peninsula. J. Sea Res. 2014, 93, 2-11.

20. Poole RW. An introduction to quantitative ecology. New York: McGraw-Hill, 1974.

21. Poornima, K. Thennarasu, R. Ranith, R. Shanthi, R.K. Sarangi, and T. Thangaradjou. 2014. Nutrient Enrichment Experiment to Establish Relationship between Chlorophyll and Phosphate. International Journal of Advanced Earth Science and Engineering. 3(1), 211-224.

22. Roelke, D.L., Eldridge, P.M., and Cifuentes, L.A. A Model of Phytoplankton Competition for Limiting and Nonlimiting Nutrients: Implications for Development of Estuarine and Nearshore Management Schemes. Estuaries. 1999. 22, 92-104.

23. Subiyanto, S. 2017. Remote Sensing and Water Quality Indicators in the West Flood Canal Semarang City: Spatio-temporal Structures of Lansat-8 Derived Chlorophyll-a and Total Suspended Solids. IOP Conf. Series: Earth and Environmental Science 98, 1-10.

24. Schindler DW. 1974. Eutrophication and recovery in experimental lakes: implications for lake management. Science. 184, 897-899.

25. Schindler DW. 2012. The dilemma of controlling cultural eutrophication of lakes. P Roy Soc B- Biol. 279, 4322-4333.

26. Schindler DW, Hecky RE. 2008. Reply to Howarth and Paerl: Is control of both nitrogen and phosphorus necessary? P Natl Acad Sci USA. 105, E104-E104.

27. Schindler DW, Hecky RE, Findlay DL, Stainton MP, Parker BR, Paterson MJ, Beaty KG, Lyng M, Kasian SEM. 2008. Eutrophication of lakes cannot be controlled by reducing nitrogen input: results of a 37-year whole-ecosystem experiment. P Natl Acad Sci. 105, 11254-11258. 
28. Shaari, F., Mustapha, M.A., Ali, M.M. and Lihan, T. 2013. Chlorophyll-a and nutrient distribution of Pahang coastal waters during southwest monsoon using satellite images. AIP Conference Proceedings. 1571, 493.

29. Trommer, G., A. Leynaert, C. C. Klein, A. Naegelen \& B. Beker. 2013. Phytoplankton Phosphorus Limitation In A North Atlantic Coastal Ecosystem. J. Plankton Res. (2013) 35(6), 1207-1219.

30. Wang Y., H. Jiang, J.Jin, X. Zhang, X. Lu and Y. Wang. 2015. Spatial-Temporal Variations of Chlorophyll-a in the Adjacent Sea Area of the Yangtze River Estuary Influenced by Yang- tze River Discharge. Int. J. Environ. Res. Public Health. 12, 5420-5438. https://www.mdpi. com/1660-4601/12/5/5420/htm.

31. Wetzel, R., 1983: Limnology. 2nd Edition. Philadelphia: Saunders College Publishing.

32. Wu, Y.M.; Xu, Z.L.; Fan, W. 2009. Temporal-spatial change of concentration of Chlorophyll-a in the East China Sea during 1997-2007. Res. Environ. Sci., 21, 137-142.

33. Zhang C, Han M. 2015. Mapping chlorophylla concentration in Laizhou Bay using Landsat 8 OLI data. Proceedings of the 36th IAHR World Congress. Netherland. 